\title{
Learners and their expectations for an integrated informatics environment
}

\author{
Alison I. Griffith \\ Gene Diaz \\ University of New Orleans, USA \\ Cassandra Murphy \\ Tulane University, USA
}

\begin{abstract}
This paper explores students' expectations for an integrated informatics environment. We interviewed students from four secondary schools in New Orleans, LA. Our data show an unsettling lack of critical investigation in courses about informatics technology. Nonetheless, students have developed critical understandings of computers in society based on futurist portrayals of society on television and in popular films. Their expectations are mediated by social class. Working class and minority students are more likely to see the social contradictions of informatics technology than are other students.
\end{abstract}

Keywords: classroom practice, curriculum policies, knowledge representation, research, visions 


\section{INTRODUCTION}

Issues of equity and access, shaped by the inequalities of gender, race and class, have been identified by many educators as central to understanding the uneven development of informatics implementation in U.S. schools. We suggest there is an additional and perhaps primary issue. In schooling, courses and resources are focused on acquisition of the technical information which precludes the development of an informed and critical exploration of the impact of informatics on society $[1,2,3]$.

This pilot study explores students' expectations for the shape and character of informatics in their future. As we have explored this topic with secondary school students in New Orleans, Louisiana, we have discovered an unsettling gap in the computer curriculum. The social organization of computer knowledge is rarely explored in secondary school courses. Students have little basis in their schooling for developing an informed and critical stance towards the impact of informatics on society. In our research, we found that secondary-school students had developed a vision of an informatics-based future derived from futurist portrayals on television and in film. Students' describe both positive and negative consequences of future informatics uses in society. Our research suggests that technical skills-oriented curricula displaces a critical and informed discussion within schooling about informatics - a dialogue which is currently conducted between the student and the media. This dialogue is mediated by social class positioning - working class and minority students are more likely to see the social contradictions of informatics than are other students.

\section{EQUITY, ACCESS AND SOCIAL CLASS IN EDUCATION}

As we move toward the 21 st Century, schools in the U.S. continue their uneven training and education of students for a society in which informatics plays an ever-increasing role. Consistently, researchers have shown that issues of equity and access in educational computing are directly related to students' ability classification, gender, race/ethnicity and socio-economic status $[4,5,6,7]$. Becker [4] suggests that issues of student access are predicated on the availability of computers and, as importantly, on teachers' ability to incorporate computer-oriented analytic thinking and problem solving into their classroom activities. Kirby and 
Styron [8] examine the issue of access to technology as a function of ability, race and gender. In Louisiana, computer access appears to be mediated by academic expectations held by teachers and administrators. We can expect, therefore, that student knowledge of and expectations for the limits and possibilities of informatics will reflect the differences of equity and access that permeate educational technology courses in the U.S.

The equity and access literature is limited in its ability to contextualize educational computing within the larger institution of schooling. This research gives us some understanding regarding school-generated differences in student knowledge about educational computing and yet, describes only part of the picture. These studies rely on a liberal conception of schooling with a focus on individual rights and responsibilities. Within this framework, problems of equity and access are conceived of as technical problems of student access and teacher training.

When we place the concerns of equity and access in the context of schooling, we find they do not stand in isolation from, but rather mirror the relations of inequality constructed within education [9]. Social class membership is strongly constitutive of school outcomes [10]. The social relations of class position working class and minority students differently from middle class students. Most working class students have less investment in the hegemonic structures of schooling and their marginality provides for the possibility of a critique of schooling. This is not to claim that the critique is necessarily a sophisticated one. Rather, it is to suggest that the oppositional stance of working class and minority students provides the basis for a critical stance toward schooling. In the case of educational computing, our data show that working class and minority students are more likely to see the social contradictions inherent in informatics than are their middle class counterparts.

Bowers [1] claims that the emphasis in educational computing on technology and individualism inhibits critical analyses of informatics technology. Computing curricula that do not raise questions about the limitations of knowledge available technologically encourage "digitized thinking" and preclude critical discussions of the complexities of informatics in society. As described by Cummins [11, p.viii], the computer is conceived of as an "adjunct transmitter of knowledge and skills".

The students we interviewed were critical of technological processes taking place in society. As we will see below, the critique is based first in the social relations of class and race that marginalize working class and minority students, their families and their communities; and second, in the futurist portrayals of television and media which both glorify 


\section{Integrating information technology into education}

technological possibilities and introduce the expectation of social distress. Critical knowledge about informatics technology is only minimally grounded in students' schooling experience.

\section{METHODOLOGY}

We conducted group interviews with students in four secondary schools in New Orleans, LA USA. The schools included two public magnet schools (known here as Mondrian and McClintock Schools), a private school (Pious School) and a comprehensive public secondary school (Downtown School). Mondrian and Pious Schools enroll primarily

students from middle income families; McClintock School draws from a wide range of families but includes a substantial number of students from low income families; Downtown School students are typically from families with low incomes. All the students we interviewed at the public schools were African-American while those at the private school were European-American. The students ranged in age from 14 to 19 years (Grades 9, 11, and 12) and were enrolled in computer literacy or computer science courses. We also informally interviewed their teachers.

The group interviews were conducted during class time and typically held in the school library. One interview was held in one corner of the classroom. The University of New Orleans Human Subjects Review regulations required we interview only students whose parents signed consent forms. In total, 30 students were interviewed.

The interviews were tape recorded and selectively transcribed by the researchers. We looked for themes and patterns within the interview data that were consistent across all the student interviews. As well, we reviewed the literature in the area of educational computing in order to discover areas of overlap with our data.

The student population in New Orleans should not be seen as representative of student populations in the rest of the United States. First, the diversity of the U.S. population means that there are vastly different ethnic, racial and class configurations across the country. Second, Orleans Parish is an urban centre which has an African-American majority and a wide range of minorities including Hispanics, Asians and EuropeanAmericans. Third, the different race/ethnic groupings, such as the AfricanAmericans, are found throughout the class structure of New Orleans. Fourth, the graduation rate for Louisiana is one of the lowest in the U.S. The students we interviewed are more likely to be those who will complete their secondary school education. 
This has implications for the relationship between our findings and other research in the area. For example, our research will not show the wide range of differences in educational computing by race or gender. However, class differences are very evident. Thus, we have focussed on social class as it shapes the different experiences and expectations of students about informatics.

\section{DISCUSSION}

The interviews with the students brought into view several patterns of use and understanding. Computer access and use patterns supported the findings of the literature on equity and access cited above. Other patterns included differences in students' expectations for the role of informatics in their future and the role of the media in constructing these expectations.

\section{Differences in access}

Our interviews showed patterns of educational computing shaped by social class. Differences in access and resources available to the four groups of students were closely linked to family and school resources social class. At Mondrian School, all of the students we interviewed had computers at home. So, too, did the students at Pious School. However, only one of the students interviewed at McClintock School and one student at Downtown School had a home computer although several students claimed to have access to computers through friends.

The amount of time students spent on computers reflected social class resources available to them through their schools. At Mondrian School and Pious School, the students worked at computers for 30 minutes, three or four days of the week. McClintock School which focuses on mathematics and science had just cut the amount of time in which students are engaged in computer courses to once per week ( $20 \%$ of the students' mathematics grade). Downtown School students spent the least amount of time on computers and had fewer computer resources to draw on than did other students with whom we spoke. They spent little time actually using computers because most of the classroom computers were not functioning. Often they had to share the computer with several students. During this school year, they have had five substitute teachers in their computing course. Their current teacher was uncertified in the subject area but was concerned that students be able to finish the computer science course. 


\section{Integrating information technology into education}

\section{Differences in critical knowledge}

Obviously, the different school experiences and the range of resources available to them will have an impact on these students' knowledge about computers. What is not as obvious is the relation between their critical understandings about computing and their social class.

We asked students to tell us about a future in which informatics was integrated into their everyday lives. They described a number of scenarios they thought might be possible. One of the scenarios included schooling in the future. The students said that teachers would become obsolete and that all learning would be done through computers. The students at Pious School were concerned that this would reduce the experiential learning that is part of the school experience. Pious and Mondrian students said there would be a computer on every desk and that every student would have a laptop and a computer at home. Generally, students at Mondrian and Pious described technological changes based on informatics as "...for the best". On the other hand, students at McClintock and Downtown were much more pessimistic about an informatics-based future. Downtown and McClintock students envisioned a future without schools where students could educate themselves at home through computer-assisted instruction. The McClintock students described a scenario in which they did their lessons on the computer during the day and then went out with their friends in the evening.

For our purposes here, it is the underlying conception of computers as knowledge transmitters that is of interest. This conception of computers supports the "transmission-internalization duet" [11] $p$ viii, of current curricular models. While most pronounced at McClintock and Downtown, this vision of informatics was held by all of the students. Noble claims that computer-based education research and development is grounded in a conception of "sophisticated man-machine systems" [3] p 188 , - a conception which shapes these student expectations of informatics as well. The computer is seen as a machine that (potentially) contains all the school knowledge students need. In the future described by the McClintock and Downtown students, the computer-student link will separate students from schools but not from their communities.

\section{Computers and the future}

We asked the students two kinds of questions about their expectations of future uses of informatics. First, we asked them to describe computers in the 21 st Century. We reminded them that 1994 was six years from the turn of the century, and asked them which of their visions of a future including informatics would be part of everyday life. 
The student descriptions of informatics futures were revealing. They described a future that included talking books, computers on each student desk, computers that would recognize householders' voices for setting home security systems; voice recognition computers that produced hamburgers on demand; computer-controlled flying cars; medical advances and so on. Their descriptions of the year 2000 were more technologically moderate and included voice-recognition computer systems, increased police surveillance strategies, more sophisticated software for training pilots, and communications systems that included video cameras.

We saw no basis for their critical visions either in course materials, or in curriculum guides [12], all of which are skills-based, some of which teach a technological history of informatics.

The wide-ranging student descriptions of informatics technology for the future ranged from the fantastic to the concrete. The student descriptions were replete with excerpts from television and films that represented the future. For example, several students remarked on the American Telephone and Telegraph (AT\&T) commercial showing a mother checking on her sleeping baby using a video monitor. Other students mentioned films such as Total Recall as an example of the future of informatics technology. Indeed, man-machine films and television programs such as Star Trek: The Next Generation and The Jetsons were cited as the basis for their conceptions of an informatics future.

When asked if they could see any drawbacks to the technology they had envisioned, the responses varied by school and social class. For example, most of the Pious students thought that informatics technology would be congruent with their careers and interests. The Mondrian and McClintock students asserted that technological advances would mean people would become lazy. The Mondrian, Downtown and McClintock students suggested it would make work easier. They also described other, more formidable consequences for informatics technology. One student at Pious and several students at Downtown and McClintock suggested that computers would contribute to the development of advanced war machines. The McClintock students and the Downtown students had the most pessimistic expectations for informatics. Downtown students suggested that people would be "laid off" because of robotics. Another suggested that the future was jeopardized by "mad scientists" and the possibility of nuclear warfare. These doomsday scenarios indicate a mistrust of both technology and the technologically adept.

With some exceptions, our data point to some intriguing differences in critical reflection about computers in society. First, the middle class 
students tended to describe computers in neutral ways. The working class students, on the other hand, described informatics as having both positive and negative consequences. Second, the students from lower income families were more focused on the social impact of computers in their lives while the middle income students described computers as tools for their future careers.

\section{CONCLUSION}

We suggest that the differences are linked to the different social positioning of the two groups of students. Low income students (the majority of those we interviewed from McClintock and Downtown schools) are more 'at risk' of failure in the schooling process. In New Orleans, working class neighborhoods are often unsafe and, at times, public schools are visited by street violence. One student at McClintock said: "Nobody won't be here if peoples keep killing each other. Nobody going to be here to see no computers." As well, the relevance of the school curriculum to the lives of inner city students is questionable. There are often significant differences between the school curriculum and their lives outside school. Thus, points of contradiction are present in their schooling experience - contradictions that generate oppositional and critical possibilities. In contrast, the middle income students' experience of schooling (at Mondrian and Pious schools) is more congruent with, and linked to individualist understandings of their lives outside schooling.

Of equal importance in developing particular visions of an informatics future are differences in television and film viewing patterns between classes. The Downtown and McClintock students mentioned media-based scenarios more often than did the Mondrian and Pious students. As the Louisiana secondary school curriculum for educational computing focuses on skill-building and ignores critical analysis, students projections for their future in informatics technology develops through their exposure to the media. Their expectations for an integrated informatics environment are shaped outside of schooling, in television and films in which computers are transmitters of objective, factual knowledge. In both settings, the possibilities for a questioning stance about the impact of informatics on society are truncated or distorted.

Our research shows that students have a critical understanding of informatics that is mediated by the social relations of class. A critically-oriented curriculum for informatics technology courses has been recommended by theorists such as Bowers [1] and developed by 
educational researchers such as DeVillar and Faltis [6]. The implementation of such curricula in US schools would provide students' with an opportunity for critical reflection on technology.

\section{REFERENCES}

1. Bowers, C. A. (1988) The cultural dimensions of educational computing: Understanding the non-neutrality of technology. New York: Teachers College Press.

2. Griffith, A. I. (1992) Educational computing in the elementary classroom. Education and Computing. 8, 53-60.

3. Noble, Douglas D. (1991) The Classroom Arsenal: Military research, information technology and public education. New York: Falmer Press.

4. Becker, H. (1990) Computer Use in United States Schools: 1989 - an initial report of U.S. participation in the I.E.A. computers in education survey. M.D. Center for Social Organization of Schools. Baltimore MD: The Johns Hopkins.

5. Cusick, T. (1986) Beyond the Star Trek Syndrome to an Egalitarian Future: Where No One has gone before. Washington, DC: NOW Legal Defense and Educational Fund. ERIC Document Reproduction No. ED 304130.

6. Devillar, R. A., and Faltis, C. J. (1991) Computers and Cultural Diversity: Restructuring for School Success. Albany NY: State University of New York Press.

7. Malcolm, S. M. (1988) Technology in 2020: Educating a diverse population in Technology in Education: Looking toward 2020, Eds R. S. Nickerson and P. P. Zodhiates, 216-30. New Jersey: Lawrence Erlbaum Associates.

8. Kirby, P. C., and Styron, R. (1993) Access to technology as a function of ability, race, and sex. Paper Presented at the Annual Meeting of AERA. Atlanta.

9. Apple, M. (1988) Teachers and Texts: A political economy of class and gender relations in education. London: Routledge and Kegan Paul.

10. Griffith, A. I., \& Smith, D. E. (1990) 'What did you do in school today?' Mothering, schooling and social class. Perspectives on Social Problems 2, 3-24. 
11. Cummins, J. (1991) Foreword. In Computers and Cultural Diversity: Restructuring for school success, R. A. DeVillar, and C. J. Faltis, vii-ix. New York: SUNY.

12. Louisiana State Board of Elementary and Secondary Education (1985) Computer Science curriculum guide. Baton Rouge, LA: State of Louisiana.

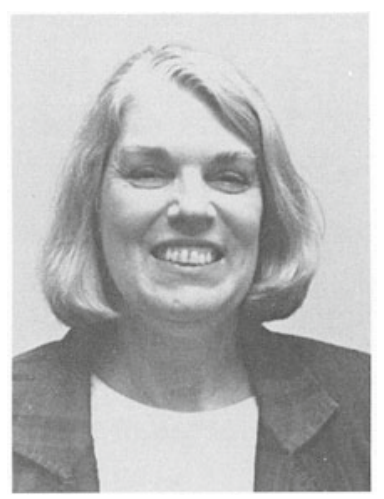

Alison Griffiths is an Associate Professor in the department of Educational Leadership, Counselling and Foundations at the University of New Orleans, Louisiana, USA. She was trained in Canada at the Ontario Institute for Studies in Education as an educational sociologist. Currently she teaches qualitative research methods and social foundations of education courses. Her research on informatics in education explores the social and critical features of educational policy and practice and investigates the social relations of discourse that construct informatics in education. 